\title{
Inherited Creutzfeldt-Jakob disease in a British family associated with a novel 144 base pair insertion of the prion protein gene
}

\author{
D Nicholl, O Windl, R de Silva, S Sawcer, M Dempster, J W Ironside, J P Estibeiro, \\ G M Yuill, R Lathe, R G Will
}

North Manchester General Hospital, Crumpsall, Manchester M8 6RB, UK

D Nicholl

S Sawcer

G M Yuill

AFRC Centre for Genome Research, Kings Buildings, Edinburgh EH9 3JQ, UK

$\mathrm{O}$ Windl

M Dempster

J P Estibeiro

R Lathe

National CreutzfeldtJakob Disease

Surveillance Unit,

Western General

Hospital, Crewe Road, Edinburgh EH4 2XU, UK

$\mathbf{R}$ de Silva

J W Ironside

R G Will

Correspondence to: Dr R de Silva.

Received 5 April 1994

and in revised form

13 July 1994

Accepted 20 July 1994

\begin{abstract}
A case of familial Creutzfeldt-Jakob disease associated with a 144 base pair insertion in the open reading frame of the prion protein gene is described. Sequencing of the mutated allele showed an arrangement of - six octapeptide repeats, distinct from that of a recently described British family with an insertion of similar size. Thirteen years previously the brother of the proband had died from "Huntington's disease", but re-examination of his neuropathology revealed spongiform encephalopathy and antiprion protein immunocytochemistry gave a positive result. The independent evolution of at least two distinct pathological 144 base pair insertions in Britain is proposed. The importance of maintaining a high index of suspicion of inherited Creutzfeldt-Jakob disease in cases of familial neurodegenerative disease is stressed.
\end{abstract}

(F Neurol Neurosurg Psychiatry 1995;58:65-69)

Keywords: Creutzfeldt-Jakob disease; prion protein gene; mutations; base pair insertion

Between $6 \%$ and $15 \%$ of cases of CreutzfeldtJakob disease may be familial with an autosomal dominant pattern of inheritance. ${ }^{12} \mathrm{~A}$ variety of point mutations and base pair insertions of the open reading frame of the prion protein gene have been reported to cosegregate with cases of inherited Creutzfeldt-Jakob disease. ${ }^{3-6}$ The pathogenicity of these mutations is suggested by their absence in normal subjects, ${ }^{78}$ and the apparent development of spontaneous neurodegeneration in transgenic mice carrying the murine equivalent of the leucine substitution at codon $102^{9}$ (characteristically associated with Gerstmann-Straussler syndrome ${ }^{10}$ ). The region between codons 51 and 91 of the open reading frame normally comprises one nonapeptide and four octapeptide repeats. ${ }^{11}$ Insertions of two and between five and nine extra octapeptide repeats have been associated with Creutzfeldt-Jakob disease. ${ }^{356}$ In their paper on a large family from the south east of England with a 144 base pair insertion (six extra repeats), Collinge et al described the remarkable diversity of clinical and neuropathological features of affected cases. ${ }^{12-14}$ The nucleotide sequence of the mutated allele in this family showed that the 144 base pair insertion had remained stable over at least six generations. ${ }^{8}$ In the current communication another British family with a base pair insertion of similar size but novel sequence (unrelated to the original family) is described. There were remarkable similarities to the first pedigree with respect to the diversity of clinical features in affected members.

\section{Case report}

The propositus (III.6, fig 1) presented aged 46 with a two month history of progressive visual disturbance and unsteadiness. He was unable to operate machinery at work and seemed less concerned about his performance. One month before admission he could not recognise large objects or relatives' faces, and by the time of his admission could only distinguish between light and dark. By then he had difficulty standing independently. Medical history was unremarkable, and he took no medication. He smoked 20 cigarettes daily and consumed 4 units of alcohol monthly. On examination he was euphoric, disoriented in time, and had impaired short term memory (with confabulation). He was mildly dysphasic. He could not perceive hand movements, but pupils were equal with normal responses to light stimulation. There was tremor on maintained posture of his arms. 
Tone and reflexes were physiological and symmetric, and plantar responses were downgoing. Gait was unsteady.

The following investigations were normal or negative: routine biochemistry and haematology, liver function tests, autoantibody profile, syphilis serology, TSH, copper studies, and HIV serology. Examination of CSF showed 4 lymphocytes per $\mathrm{mm}^{3}$ and a protein content of $0 \cdot 16 \mathrm{~g} / \mathrm{l}$. Computerised tomography showed enlarged ventricles, and cerebral and cerebellar cortical atrophy. Electroencephalography showed bilaterally synchronous, repetitive, triphasic discharges at 1 per second on a background of slow rhythms. Pattern reversal visual evoked potentials could not be performed, and in response to a flash stimulus the late components were dispersed (P3 at $178 \mathrm{~ms}$ bilaterally).
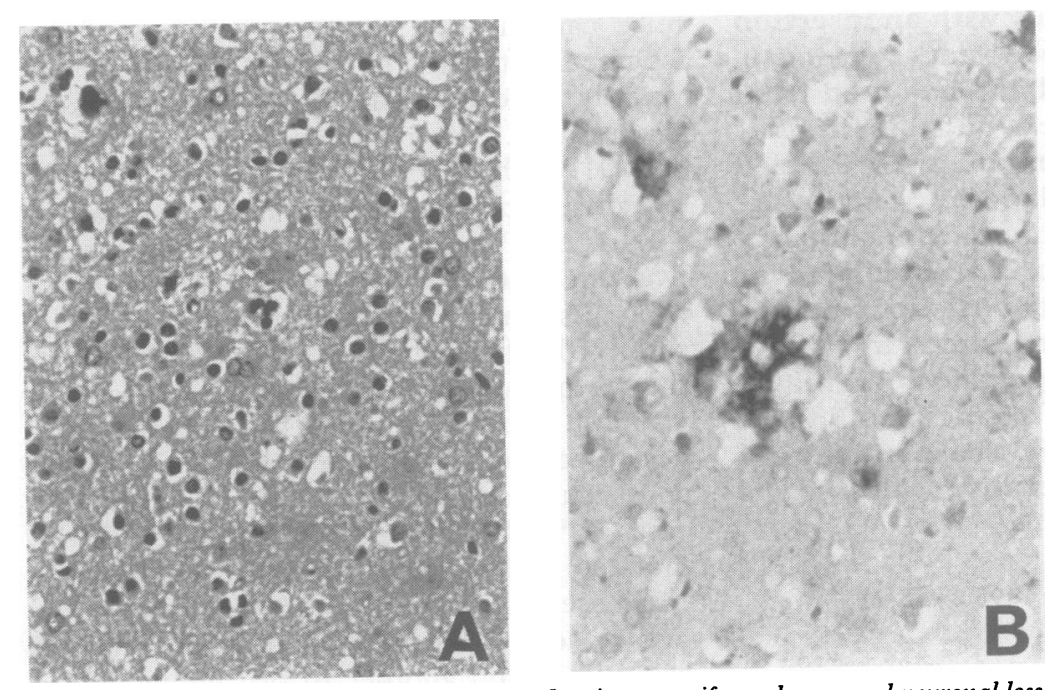

Figure 2 (A) Occipital cortex in case III.6 showing spongiform change and neuronal loss with severe reactive astrocytosis (haematoxylin-eosin, originally $\times 200$ ).

with severe reactive astrocytosis (B) protein showing a positive reaction with a dark stain (B) Immunocytochemistry for prion protein showing a positive reaction with a dark stiotin product around areas of confluent spongiform change in the occipital cortex (avidin-
reaction after hydrolytic autoclaving and haematoxylin counterstain, originally $\times 240)$.
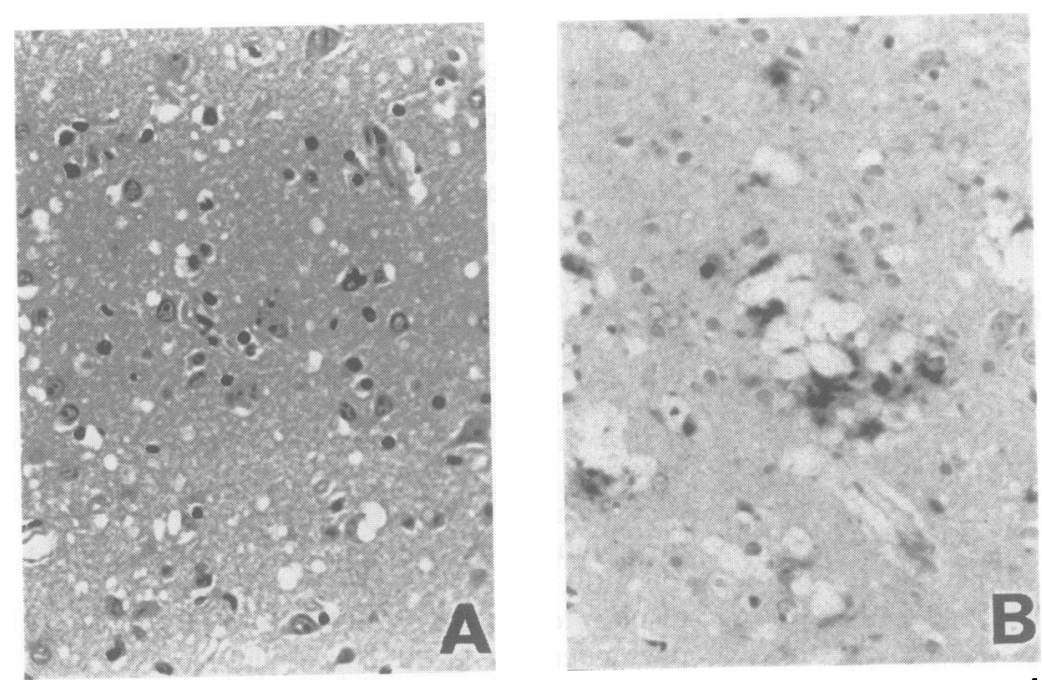

Figure 3 (A) Putamen in case III. 4 showing confluent spongiform change with neuronal loss in an irregular distribution (haematoxylin-eosin, originally $\times 200$ ).

loss in an irregular distribution (haematein showing dense deposition of the dark reaction (B) Immunocytochemistry for prion protein showing dense deposition of the daridiotin product around areas of confluent spongiform change in the putamen (avidin-biotin 240 ).
Myoclonic jerks were noted soon after admission, and he developed dressing apraxia. Frontal release signs recurred, and paratonic rigidity of his limbs emerged. Gait ataxia worsened and he became bedbound. Terminally he had rest and startle myoclonus, and became akinetic and mute. He died one month after admission.

The patient's brother III.4 (fig 1) was thought to have died from Huntington's disease at the age of 39,13 years previously. His terminal illness had been of five years' duration, and had been characterised by choreiform movements, gait disturbance, and dementia. Several other members of the pedigree had also succumbed to dementing illnesses, variously described as "shellshock", Huntington's disease, general paralysis of the insane, and "organic dementia" (fig 1). After his brother's presentation, III.4's neuropathology was reviewed.

\section{Materials, methods, and results \\ NEUROPATHOLOGY}

After necropsy, the brain from case III. 6 was fixed in $10 \%$ formalin and submitted to the National Creutzfeldt-Jakob disease Surveillance Unit for investigation. The fixed brain weighed $1234 \mathrm{~g}$ and showed a moderate degree of cortical atrophy in the cerebral hemispheres. No other relevant external abnormalities were noted. Tissue blocks from all cortical areas, the basal ganglia, thalamus, hypothalamus, brainstem, and cerebellum were decontaminated in $96 \%$ formic acid for one hour before routine processing into paraffin wax. Five $\mu \mathrm{m}$ sections were cut and stained by conventional histological techniques and by immunocytochemistry for prion protein using a polyclonal antibody raised against scrapie associated fibrils (courtesy of Dr J Hope, MRC/AFRC Neuropathogenesis Unit, Edinburgh).

From case III.4, unstained paraffin sections were obtained from the cerebellum, frontal, parietal, temporal, and occipital lobes, basal ganglia, and thalamus. These were stained by conventional histological techniques and by immunocytochemistry for prion protein as described earlier.

In case III.6, the sections of the cerebral hemispheres showed a spongiform encephalopathy involving the cerebral cortex in a widespread distribution with particularly severe occipital and parietal involvement. Reactive gliosis in these regions was conspicuous as well as spongiform change and neuronal loss. The visual cortex showed status spongiosus. Spongiform change was noted in the basal ganglia, particularly involving the putamen, and was also noted in a patchy distribution throughout the molecular layer in the cerebellar cortex. Prion protein immunocytochemistry showed a positive reaction in the cerebral cortex within and around areas of spongiform change (fig 2 ). In the cerebellum, focal deposition of prion protein was accompanied by a more diffuse staining in the granular layer. No evidence of Huntington's 


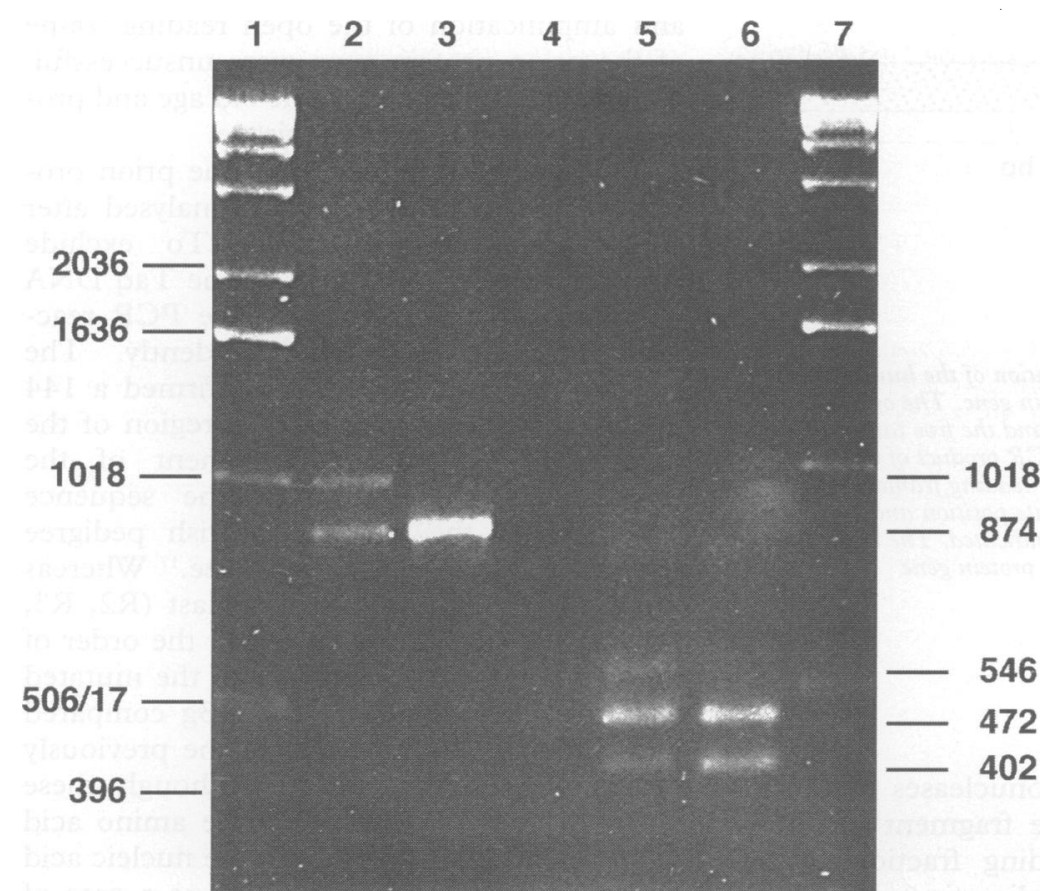

Figure 4 Analysis of prion protein gene PCR products by gel electrophoresis. $10 \mu \mathrm{l}$ of each PCR reaction was loaded directly (lanes 2-4) or after PvuII digest (lanes 5 and 6). $P C R$ was performed on genomic DNA of patient III. 6 (lanes 2 and 5) and an unrelated patient without any mutation of the open reading frame of the prion protein gene lanes 3 and 6). A PCR reaction with no template DNA was added as a contamination control (lane 4). The sizes of the PCR products were estimated by comparison with marker DNA (lanes 1 and 7,1 kb ladder, GicoBRL; sizes on the left in $b p$ ). Calculated values of the published human prion protein gene sequence fragments are given in bp on the right.

disease or any other primary neurodegenerative disorder was noted. Occasional blood vessels in the deep grey matter and central white matter regions showed arteriosclerosis with patchy calcification but there was no evidence of appreciable ischaemic damage.

In case III.4, spongiform change was noted in a patchy distribution in the cerebral hemi- spheres, most conspicuously in the temporal and frontal lobes. Cortical atrophy in these regions was accompanied by neuronal loss and reactive gliosis. Spongiform change was also present in a patchy distribution in the cerebellar cortex and the basal ganglia. There was no evidence of Huntington's disease or any other primary neurodegenerative disorder. Immunocytochemistry for prion protein showed a patchy positive reaction in the cerebral cortex in relation to areas of spongiform change (fig 3). Occasional astrocytes also showed punctate prion protein immunoreactivity within the cytoplasm.

\section{MOLECULAR BIOLOGY}

Genomic DNA was extracted from the blood of patient III. 6 and control subjects by standard techniques. ${ }^{15}$ The open reading frame of the prion protein gene was amplified by the polymerase chain reaction (PCR) in a $50 \mu \mathrm{l}$ reaction containing $1 \mu \mathrm{g}$ of genomic DNA, 50 $\mathrm{mM} \mathrm{KCl}, 10 \mathrm{mM}$ Tris $\mathrm{HCl}(\mathrm{pH} \mathrm{9.0)}, 0 \cdot 1 \%$ Triton X-100, $1.5 \mathrm{mM} \mathrm{MgCl}_{2}, 0.2 \mathrm{mM}$ of each deoxynucleotide triphosphate, $1 \mu \mathrm{M}$ of each oligonucleotide primer, and 2.5 units Amplitaq DNA polymerase (Perkin Elmer Cetus). The sequence of the oligonucleotide primers were 5'-CGCAAGCTTGAACTCTGAACATTCTCCTCTTC-3' and 5'-TTCGAATTCCTCCCTCAAGCTGGAAAAAG$3^{\prime}$, which are situated $5^{\prime}$ or $3^{\prime}$ to the human open reading frame of the prion protein gene. ${ }^{16}$ The mixture was overlayered with mineral oil and subjected to 35 temperature cycles $\left(0.5^{\prime} 95^{\circ} \mathrm{C}, 1^{\prime} 55^{\circ} \mathrm{C}, 2^{\prime} 72^{\circ} \mathrm{C}\right)$ in an Omnigene thermal cycler. To analyse the product, $10 \mu \mathrm{l}$ of the reaction was loaded on to a $1.5 \%$ agarose gel either directly or after cleavage with the restriction endonuclease PvuII, electrophoretically separated, and stained with ethidium bromide. To clone and sequence the PCR products, they were cut

Sequence comparison of the normal and mutated tandem repeat regions of the prion protein gene

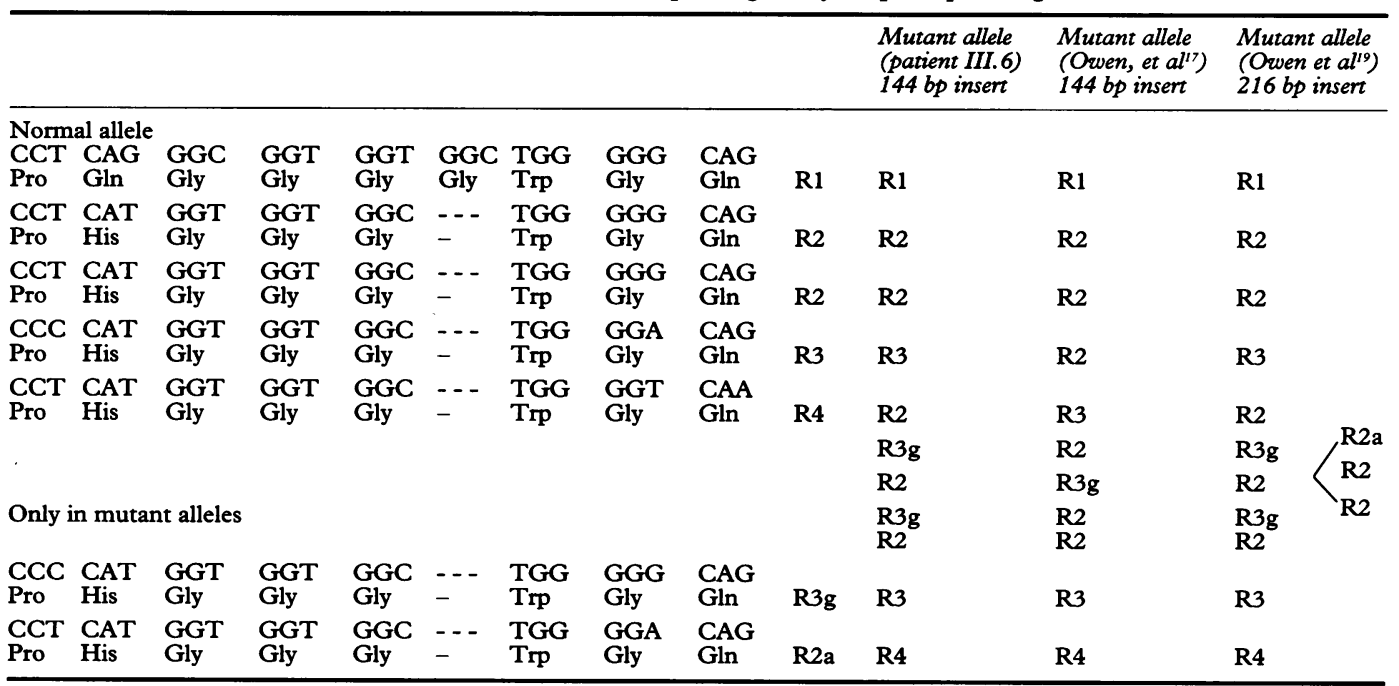

Repeats are named according to the proposed nomenclature of Goldfarb et al ${ }^{4}$ and the top to bottom order reflects the 5' to 3' direction. The nucleotide and amino acid sequences of the repeats in the normal allele and of the repeats R2a and R3g, unique to mutated alleles, are presented. Silent nucleotide changes in R2a, R3, R3g and R4 compared with R2 are underlined. The differing regions between the mutated alleles with $144 \mathrm{bp}$ are printed in bold, and the position of the three additional repeats in the allele with a 216 bp insert is indicated. 


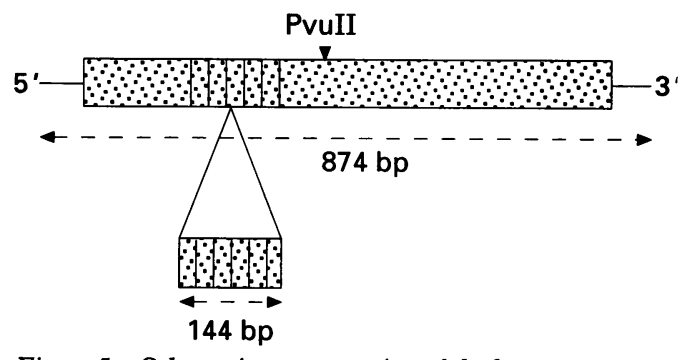

Figure 5 Schematic representation of the human open reading frame of the prion protein gene. The open reading frame is shown as a dotted bar and the five tandem repeats are indicated. The size of the PCR product of a normal allele $(874 \mathrm{bp})$ exceeds the open reading frame at the $5^{\prime}$ and 3 ends, and the approximate position and scale of the six repeat inserts (144 bp) are indicated. The restriction enzyme PouII cleaves the prion protein gene asymmetrically.

with the restriction endonucleases $\mathrm{MspI}$ and Sau3A to create a large fragment including most of the open reading fraction of the prion protein gene. The digestion products of the alleles were isolated from an agarose gel separately. They were cloned into the vector pBluescriptIIKS(-) (Stratagene), that was itself cut with the enzymes Cla I and BamH I to create compatible ends. The inserted open reading frame was sequenced with SequenaseII (United States Biochemicals) as double stranded material according to the manufacturer's recommendations. The sequencing primers used were either the T3 and $\mathrm{T} 7$ primers (Stratagene) or the synthetic oligonucleotides 5'-TGGCACCCACAGTCAGT-3' and 5'-TTCTCCCCCTTGGTGG$\mathrm{T}-3^{\prime}$, which correspond to internal sequences of the human open reading frame of the prion protein gene. ${ }^{16}$

Agarose gel electrophoresis of the PCR products from the genomic DNA of III. 6 showed two major products of about $850 \mathrm{bp}$ and $1000 \mathrm{bp}$ in size (fig 4, lane 2). This indicated that one prion protein allele in III. 6 had an insertion of about $150 \mathrm{bp}$. In normal subjects (and patients with Creutzfeldt-Jakob disease without extra octapeptide repeats in their prion protein gene) both prion protein alleles are represented by a single $850 \mathrm{bp}$ fragment (fig 4, lane 3). A digest of the PCR amplified material with the restriction endonuclease PvuII showed in a normal subject two fragments of $400 \mathrm{bp}$ and $470 \mathrm{bp}$, corresponding to the $5^{\prime}$ and $3^{\prime}$ parts of the gene respectively (fig 4, lane 6; fig 5). The same treatment of the PCR product of III.6 showed a third band at about 550 bp (fig 4, lane 5) indicating the presence of an insertion of about $150 \mathrm{bp}$ in the $5^{\prime}$ part of the gene. This localisation matched to the only known insertion site within the prion protein gene that is associated with familial Creutzfeldt-Jakob disease, the octapeptide repeat region, and the size estimation of the mutated PCR product was compatible with a 144 bp insertion (fig 5).

Archival CNS tissue from III.4 was available, but several attempts at DNA extraction and amplification of the open reading frame of the prion protein gene were unsuccessful. This was probably due to the old age and prolonged fixation time of the tissue.

The open reading frame of the prion protein gene of III. 6 was further analysed after subcloning and sequencing. To exclude amplification errors caused by the Taq DNA polymerase, the products of five PCR reactions were analysed independently. The results were consistent and confirmed a 144 bp insertion in the octapeptide region of the mutated allele. The arrangement of the repeats was different from the sequence described in the previous British pedigree with an insertion of the same size. ${ }^{17}$ Whereas the first (R1, R2, R3) and the last (R2, R3, R4) three repeats were identical, the order of the five repeats in the middle of the mutated allele was R3, R2, R3g, R2, R3g compared with R2, R3, R2, R3g, R2 in the previously described pedigree (table). Although these changes have not influenced the amino acid sequence of the octapeptides, the nucleic acid sequence clearly establishes this as a case of familial Creutzfeldt-Jakob disease with a novel $144 \mathrm{bp}$ insertion in the octapeptide repeat region of the prion protein gene.

\section{Discussion}

The clinical course of the propositus was typical of Heidenhain's variant of CreutzfeldtJakob disease. ${ }^{18}$ In this form occipital blindness is an early and prominent feature, and seems to correlate with severe spongiform change of the visual cortex (as here). The finding of an insertion of 144 extra base pairs in the $\mathrm{N}$-terminal octapeptide repeat region of the open reading frame of his prion protein gene was consistent with familial CreutzfeldtJakob disease. Re-evaluation of his brother's neuropathology confirmed the presence of spongiform encephalopathy, although due to technical reasons an identical insertion in his prion protein gene could not be demonstrated. Other members of this pedigree had been diagnosed as having a variety of neurodegenerative illnesses, and the variety of labels attached to them in previous generations is remarkably similar to the previously reported pedigree from the south east of England. ${ }^{12}$ Although the size of the insertion was identical in these two families, there was no known relationship and, as demonstrated, the sequence of the extra repeats was different. Given the similar size of the insertion and the identical amino acids encoded, however, it is hardly surprising that a similar spectrum of clinical phenotypes was noted.

Various sizes of insertions of the open reading frame of the prion protein gene have been associated with familial CreutzfeldtJakob disease. ${ }^{356}$ Recently Duchen et al have described a family with nine extra repeats, ${ }^{519}$ and although larger by three extra repeats the similarity in sequences between this and the insertion in the present report is noteworthy (table). The complete octapeptide repeat sequence of the current family can be 
represented by the first six and the last five repeats of the larger sequence. There is insufficient knowledge at present regarding the mechanisms leading to the generation of extra repeats to judge whether the similarities in the sequences of the extra repeats in these two pedigrees arose by chance or whether they evolved from a common ancestor.

The clinical illness of III.4 was compatible with Huntington's disease with choreiform movements, progressive intellectual decline, and a family history of neurodegenerative disease. Neuropathological findings in this case and the clinical, neuropathological, and molecular biological findings in his brother, however, make this diagnosis untenable. The gene mutation responsible for Huntington's disease has been identified recently, ${ }^{20}$ but cases of hereditary chorea without this mutation (an expansion of a trinucleotide repeat sequence) are described. ${ }^{21}$ Familial Creutzfeldt-Jakob disease is clearly an important diagnosis to bear in mind in these cases. Expansions of trinucleotide repeat sequences are increasingly recognised in inherited neurological disease, and seem to correlate with the clinical phenomenon of anticipation. ${ }^{22}$ This is not a clinical feature of inherited Creutzfeldt-Jakob disease, and as noted from the molecular biological perspective, there is stability in octapeptide repeat sequences in successive generations.

The present report emphasises the importance of neuropathological examination in cases of undiagnosed dementia, although Creutzfeldt-Jakob disease as a cause seems to be rare. ${ }^{23}$ Nevertheless, the importance of establishing this diagnosis, especially where it has implications for succeeding generations, is readily apparent. The feasibility of offering presymptomatic diagnosis to families with inherited Creutzfeldt-Jakob disease has already been investigated. ${ }^{24}$ This was complicated, however, not only by ethical dilemmas, but also by methodological problems (the less efficient amplification of alleles carrying insertions in PCR). These are likely to be especially acute when considering antenatal diagnosis.

Necropsies were performed by Dr De Kretser and Dr Brown at the North Manchester General Hospital. Archival material from case III. 4 was made available by the Huntington's disease brain bank (Dr Bruton). The Centre for Genome Research receives funding from the AFRC, and this work was supported by its BSE programme (grant No LRG 15/344). The National by its BSE programme (grant No LRG $15 / 344$ ). The National
Creutzfeldt-Jakob disease Surveillance Unit is funded by the Department of Health. Immunocytochemistry was performed by Ms C Barrie (supported by the AFRC, grant No AG by Ms C Barrie (supported by the AFRC, grant No AG
15/610). Mrs H Southworth and Miss J MacKenzie provided secretarial assistance.
1 Will RG, Matthews WB, Smith PG, Hudson C. A retrospective study of Creutzfeldt-Jakob disease in England and Wales 1970-1979 II: epidemiology. ff Neurol Neurosurg Psychiatry 1986;49:749-55.

2 Masters CL, Gajdusek DC, Gibbs CJ. The familial occurrence of Creutzfeldt-Jakob disease and Alzheimer's disease. Brain 1981;104:535-58.

3 Goldfarb LG, Brown P, Gajdusek DC. The molecular genetics of human transmissible spongiform encephalopathy. In: Prusiner SB, Collinge J, Powell J, Anderton $\mathrm{B}$, eds. Prion diseases of humans and animals. London: Ellis Horwood, 1992:139-53.

4 Kitamoto $T$, Ohta M, Doh-ura K, Hitoshi S, Terao Y, Tateishi J. Novel missense variants of prion protein in Creutzfeldt-Jakob disease or Gerstmann-Straussler syndrome. Biochem Biophys Research Commun 1993;191: 709-14.

5 Duchen LW, Poulter M, Harding AE. Dementia associated with a 216 base pair insertion in the prion protein gene. Brain 1993;116:555-67.

6 Goldfarb LG, Brown P, Little BW, Cervenakova L Kenney K, Gibbs CJ, Gajdusek DC. A new (two-repeat) octapeptide coding insert mutation in Creutzfeldt-Jakob disease. Neurology 1993;43:2392-4.

7 Doh-ura K, Tateishi J, Sasaki H, Kitamoto T, Sakaki Y. Pro to Leu change at position 102 of prion protein is the most common but not the sole mutation related to merstmann-Straussler syndrome. Biochem Biophys Research Commun 1989;163:974-9.

8 Poulter M, Baker HF, Frith CD, Leach M, Lofthouse $R$ Ridley RM, et al. Inherited prion disease with 144 base pair gene insertion 1 . Genealogical and molecular studies. Brain 1992;115:675-85.

9 Hsiao K, Scott M, Foster D, Groth DF, DeArmond SJ, Prusiner SB. Spontaneous neurodegeneration in transgenic mice with mutant prion protein. Science 1990 250:1587-90.

10 Hsiao K, Baker HF, Crow TJ, Poulter M, Owen F, Terwilliger $\mathrm{JD}$, et al. Linkage of prion protein missense variant to Gerstmann-Straussler syndrome. Nature 1989;338:342-5.

11 Owen F, Poulter $M$, Collinge J, Leach $M$, Shah $T$, Lofthouse $\mathrm{R}$, et al. Insertions in the prion protein gene in atypical dementias. Exp Neurol 1991;112:240-2.

12 Collinge J, Brown J, Hardy J, Mullan M, Rossor MN, Baker $\mathrm{H}$, et al. Inherited prion disease with 144 base pair Baker $\mathrm{H}$, et al. Inherited prion disease with 144 base pair Brain 1992;115:687-710.

13 Collinge J, Owen F, Poulter M, Leach M, Crow TJ Rossor MN, et al. Prion dementia without characteristic pathology. Lancet 1990;336:7-9.

14 Clinton J, Lantos PL, Rossor M, Mullan M, Roberts GW Immunocytochemical confirmation of prion protein Lancet 1990;336:515.

15 Sambrook J, Fritsch EF, Maniatis T. Molecular cloning: a laboratory manual, 2nd ed. New York: Cold Spring Harbor Laboratory Press, 1989.

16 Kretzschmar HA, Stowring LE, Westaway D, Stubblebine WH, Prusiner SB, DeArmond SJ. Molecular cloning of a human prion protein cDNA. DNA 1986;5:315-24.

17 Owen F, Poulter M, Shah T, Collinge J, Lofthouse R, Baker $\mathrm{H}$, et al. An in-frame insertion in the prion protein gene in familial Creutzfeldt-Jakob disease. Molecular Brain Research 1990;7:273-6.

18 Meyer A, Leigh D, Bagg CE. A rare presenile dementia associated with cortical blindness (Heidenhain's synassociated with cortical blindness (Heidenhain's syn-

19 Owen F, Poulter M, Collinge J, Leach M, Lofthouse R, Crow TJ, Harding AE. A dementing illness associated with a novel insertion in the prion protein gene. Molecular Brain Research 1992;13:155-7.

20 The Huntington's Disease Collaborative Research Group. A novel gene containing a trinucleotide repeat that is expanded and unstable on Huntington's disease chromosomes. Cell 1993;72:971-83.

21 MacMillan JC, Snell RG, Tyler A, Houlihan GD, Fenton I, Cheadle JP, et al. Molecular analysis and clinical correlations of the Huntington's disease mutation. Lancet 1993; 342:954-8.

22 Davies K. Triplet repeats on the rise. Nature 1993;364:88.

23 Brown P, Kaur P, Sulima MP, Goldfarb LG, Gibbs CJr, Gajdusek DC. Real and imagined clinicopathological limits of "prion dementia". Lancet 1993;341:127-9.

24 Collinge J, Poulter M, Davis MB, Baraitser M, Owen F, Crow TJ, Harding AE. Presymptomatic detection or exclusion of prion protein gene defects in families with inherited prion diseases. Am f Hum Genet 1991;49: inherited 